\title{
Chemoradiotherapy followed by surgery versus surgery alone in esophageal cancer patients: is it time for additional evidence?
}

\author{
Stefano Cafarotti ${ }^{1 *}$, Alfredo Cesario ${ }^{1,2}$, Venanzio Porziella ${ }^{1}$, Stefano Margaritora ${ }^{1}$ and Pierluigi Granone ${ }^{1}$
}

\begin{abstract}
Recent efforts to improve survival in patients with locally advanced esophageal carcinoma have combined both systemic and local therapy. However, the role of neoadjuvant chemoradiotherapy in technically operable Ila-III esophageal carcinoma is still unresolved.
\end{abstract}

\section{Findings}

We have read with interest the report from Hurmuzlu and coll [1] on the outcome of induction therapy (IT) plus surgery versus surgery alone in locally advanced operable esophageal cancer (OC).

The report is of great speculative interest given the consistently poor prognosis of $\mathrm{OC}$ whatever the therapeutic strategy adopted: so far, in fact, there is no general consensus on the appropriate treatment for such a dreadful condition. Specifically, the role of chemo-radiotherapy administered pre-operatively in resectable cstage IIa-III OC is still discussed.

Scarce data are available from the literature and these are not consistent. In fact some experiences $[2,3]$ conclude with positive recommendations to adopt the trimodality approach and others [4] conclude with opposite position: that IT should not be adopted in OC that are resectable following the clinical staging assessment. As already advocated by Pereira [5], the indication for IT for resectable OC remains largely not evidence-based substantially due to methodological biases in the trials that can be summarised as follows: different tumour stages included, no standardized preoperative diagnostic procedure and, last but not least, the great heterogenity of surgical treatment.

In this scenario of substantial absence of a large base of methodologically correct evidence and agreed guidelines we consider the results from [1] of significant clinical

\footnotetext{
* Correspondence: cafarottistefano@gmail.com

'Division of General Thoracic Surgery, Catholic University, Rome, Italy

Full list of author information is available at the end of the article
}

value and concur in advocating for further evidence stemming from large scale prospective randomised trials. Ideally, these should be designed valuing the past experiences to address the methodological biases with the precise task to assess whether IT should be administered before surgery in resectable OC. These trials should: a) distinguish between hystologies (squamous cell vs adenocarcinoma); b) include an optimal pre-operative staging with EUS, high quality CT and PET scan to assess the extent of the loco-regional disease and exclude distant metastases and c) include a standardized surgical treatment with extended lymph node dissection. Only by such trials the role of IT in the treatment of OC can be cleared. More convincing arguments, in fact, need to support any proposed change in clinical behaviour.

\section{Author details \\ ${ }^{1}$ Division of General Thoracic Surgery, Catholic University, Rome, Italy. ${ }^{2}$ Unit of Clinical and Molecular Epidemiology, IRCCS San Raffaele Pisana, Rome,} Italy.

Authors' contributions

All authors read and approved the final manuscript.

\section{Competing interests}

The authors declare no conflicts of interest

Received: 22 January 2011 Accepted: 19 April 2011

Published: 19 April 2011

\section{References}

1. Hurmuzlu M, Øvrebø K, Monge OR, Smaaland R, Wentzel-Larsen T, Viste A: High-dose chemoradiotherapy followed by surgery versus surgery alone in esophageal cancer: a retrospective cohort study. World J Surg Oncol 2010, 8:46.

\section{()

(C) 2011 Cafarotti et al; licensee BioMed Central Ltd. This is an Open Access article distributed under the terms of the Creative Commons Attribution License (http://creativecommons.org/licenses/by/2.0), which permits unrestricted use, distribution, and reproduction in any medium, provided the original work is properly cited. 
2. Tepper J, Krasna MJ, Niedzwiecki D, Hollis D, Reed CE, Goldberg R, Kiel K, Willett C, Sugarbaker D, Mayer R: Phase III trial of trimodality therapy with cisplatin, fluorouracil, radiotherapy, and surgery compared with surgery alone for esophageal cancer: CALGB 9781. J Clin Oncol 2008, 26(7):1086-92.

3. Knox JJ, Wong R, Visbal AL, Horgan AM, Guindi M, Hornby J, Xu W, Ringash J, Keshavjee S, Chen E, Haider M, Darling G: Phase 2 trial of preoperative irinotecan plus cisplatin and conformal radiotherapy, followed by surgery for esophageal cancer. Cancer 2010, 116(17):4023-32.

4. Burmeister BH, Smithers BM, Gebski V, Fitzgerald L, Simes RJ, Devitt P, Ackland S, Gotley DC, Joseph D, Millar J, North J, Walpole ET, Denham JW, Trans-Tasman Radiation Oncology Group; Australasian Gastro-Intestinal Trials Group: Surgery alone versus chemoradiotherapy followed by surgery for resectable cancer of the oesophagus: a randomised controlled phase III trial. Lancet Oncol 2005, 6:659-668.

5. Pereira B, Gourgou-Bourgade S, Azria D, Ychou M: Neoadjuvant chemoradiotherapy in esophageal cancer: is it still the question? J Clin Oncol 2008, 26(31):5133-4, author reply 5134.

doi:10.1186/1477-7819-9-41

Cite this article as: Cafarotti et al:: Chemoradiotherapy followed by surgery versus surgery alone in esophageal cancer patients: is it time for additional evidence? World Journal of Surgical Oncology 2011 9:41.

\section{Submit your next manuscript to BioMed Central} and take full advantage of:

- Convenient online submission

- Thorough peer review

- No space constraints or color figure charges

- Immediate publication on acceptance

- Inclusion in PubMed, CAS, Scopus and Google Scholar

- Research which is freely available for redistribution

Submit your manuscript at www.biomedcentral.com/submit
Biomed Central 